\title{
Jakarta Under Water: The 2007 Flood and The Debate on Jakarta's Future Water Infrastructure
}

\author{
Anto Mohsin 1 \\ Hobart and William Smith Colleges, Geneva, NY, USA \\ Artikel Masuk : 2 Maret 2015 \\ Artikel Diterima : 27 April 2015
}

\begin{abstract}
This paper examines the debate in the wake of the 2007 flood in Jakarta, the biggest one to occur in the city's history. By analyzing textual sources both online and in the archives as well as interviews with several actors in the debate, I demonstrate that a new sociopolitical condition in Indonesia facilitated a vibrant discourse in the wake of a so-called "natural disaster." In a democratizing society such as Indonesia, state actors no longer monopolized the social production of a "risk object" or a source of danger or harm. I show that the Indonesian public, who participated in the debate, shaped "networks of risk objects" either by "emplacing" a risk object (i.e. defining an entity as an object and linking it to a potential harm) or by "displacing" it (i.e. challenging the existence of a risk object or delinking it from a putative danger) (Hilgartner, 1992). These non-state actors managed to insert themselves into a sphere once dominated by the technocrats, in large part because the press was no longer controlled by the state. In doing so they exposed the messiness and vulnerability of the city's water management system. The "risk objects" they identified to run the whole gamut of entities that make up the entire Jakarta's water management sociotechnical system, which includes water technologies, laws, practices, institutions, conditions, policies, and the environment.
\end{abstract}

Keywords: the 2007 Jakarta flood, reformation, risk objects, socio-technical system, Jakarta's water management

\section{Introduction}

Flooding is a recurring problem in Jakarta, Indonesia. During the rainy season (October - April), a flood can affect many areas of the city. In early February 2007, several days of torrential rainstorms were followed by a devastating flood that engulfed about three-quarter of the city. The deluge paralyzed Jakarta, killed dozens of residents, and displaced around 450,000 people. Many more fell victims to waterborne diseases such as diarrhea and dengue fever. Damages due to the flood were estimated at close to US\$ 900 million. It was the largest and most destructive disaster to have occurred in the most populous city in Indonesia.

In an article that explores several water technologies and social relations in India, the U.S., and the Netherlands, Wiebe Bijker, a sociologist of technology, argues that studying 'things' of water management can help us to understand the cultural and democratic makeup of societies and for addressing questions about the further socio-technical

\footnotetext{
${ }^{1}$ Korespondensi Penulis : Hobart and William Smith Colleges, Geneva, NY, USA email : anto.mohsin@gmail.com
} 
development of those societies." 2 The idea that technology and culture are interrelated is illustrated in another of Bijker's article. In a comparative study of water management systems in New Orleans and in the Netherlands, Bijker shows that even though both systems function in what people regard as democratic societies, the two water management systems were developed differently. Bijker writes, "The American practice focuses on predicting disasters and mediating the effects once they have happened-in brief, on 'flood hazard mitigation.' Dutch practice is primarily aimed at keeping the water out." 3 The two countries, in other words, have different cultures of risk management, which in turn shaped the design of their corresponding flood control system.

Although many scholars have studied and written about the development of sociotechnical systems in mature democracies, ${ }^{4}$ little has been written about how an emerging democracy addresses the question of its socio-technical future..$^{5}$ It is within such context that the 2007 flood disaster in Jakarta and the subsequent debate about its causes and solutions relevant and important to study. Following the fall of President Suharto, the country's long time authoritarian ruler, Indonesia has been transforming into a more democratic society since 1998. One important consequence of the shift in the political situation is that technological discourses are no longer dominated by the state. The democratic movements paved the way for many non-state actors to participate enthusiastically in those discourses. In this paper, I analyze the varied responses that actors made in the wake of the 2007 flood, focusing particularly on how interested parties frame the causes and solutions to the flood problem. The debate helps understand how Jakartans (and Indonesians generally), explained a socio-technical disaster, perceived risk, and addressed the future development of the city's socio-technical system.

\section{Analytical Framework}

Actors who participated in the debate following the 2007 Jakarta flood had different reasons and objectives. Although their visions seemed to be united by a desire to prevent or mitigate future flooding, embedded in their arguments was a bigger aspiration to influence the direction of their city's development according to what they thought was right. The strategies they employed both discursively in the media and materially on the ground illustrate the mechanism by which the development of Jakarta's societies and their water infrastructure are co-constitutive.

In mapping the debate, I use the concept of "risk objects," which are defined as "things that pose hazards, the sources of danger, the entities to which harmful consequences are conceptually attached."6 I argue that actors use the flood episode to socially construct networks of risk objects for a variety of reasons and they do so in two

\footnotetext{
2 Wiebe Bijker, "Dikes and Dams, Thick with Politics," Isis, vol. 98 no. 1 (2007), p. 110 (my emphasis on the word "sociotechnical"). The term "sociotechnical" was first coined by Thomas P. Hughes in his book Networks of Power: Electrification in Western Society, 1880-1930, (Baltimore, Maryland: The Johns Hopkins University Press, 1983), p. 140, the term refers to an integrated system that consists of both technical and non-technical things that make up and interact with one another to produce a noticeable effect.

3 Wiebe Bijker, "Dikes and Dams, Thick with Politics,"p. 120.

${ }^{4}$ For examples, see Bijker "Dikes and Dams," and Sara B. Pritchard, Confluence: The Nature of Technology and the Remaking of the Rhône (Cambridge, MA: Harvard University Press, 2011).

5 See Sulfikar Amir, "Challenging Nuclear: Antinuclear Movements in Postauthoritarian Indonesia," East Asian Science, Technology and Society 2009 and Schiller, J., Lucas, A., \& Sulistiyanto, P., "Learning from the East Java Mudflow: Disaster politics in Indonesia,” Indonesia, 85 (April 2008), 51-77.

6 Stephen Hilgartner, "The Social Construction of Risk Objects: Or, How to Pry Open Networks of Risk," in James F. Short, Jr. and Lee Clarke (editors), Organizations, Uncertainties, and Risk (Boulder, CO, San Francisco, CA, and Oxford, UK: Westview Press, 1992), p. 41.
} 
ways. Actors either "emplace" a risk object (i.e. defining an entity as an object and linking it to a potential harm) or they "displace" it (i.e. challenging the existence of a risky object or delinking it from a putative danger). ${ }^{7}$ Different actors can have different interpretations of the same risk object and their understanding of which one needs to be controlled informs the kind of solution they propose. One important reason we need to understand how and why people construct risk objects is because such construction has political ramifications. Political actors deflected the blame directed at them by severing the conceptual link a risk object has with a presumed harm. Some of them argued, for example, that the 2007 flood was a natural disaster, not caused by the government's inadequate preparation and handling for such catastrophe. This way of framing the cause of flooding allowed the Jakarta government to "disown" the problem, shifting "causal, moral, and political responsibility" of flooding onto another risk object. ${ }^{8}$

I will also show that in addition to wanting to control or displace a risk object, actors proposed a solution to achieve a certain political objective. One political goal that I think was embodied in the debate about flood mitigation and prevention in Jakarta reflect a desire to advance the standing and the role of one's institution in the eyes of the public and the state. Some of the proposed technological interventions mirror a contestation between a centralized approach and a more democratic participation of socio-technical decisionmaking. Most of the state-sponsored projects aimed to strengthen the role of the state or state institutions, while other projects, typically advocated by non-state actors, aspire to achieve a more participatory approach to making technological decisions. In this paper, I highlight two proposed solutions that illustrate the competition of the two approaches in shaping the city's future socio-technical system.

\section{Situating the 2007 Flood in Indonesia's Sociopolitical Context}

Despite the regular occurrence of flooding, the 2007 flood took many Jakartans by surprise. The severity and the scope were much larger than many anticipated. Not only did the flood affect the low-lying areas in the northern part of the city, but it also submerged many more areas that had been previously spared by the floodwater, including several affluent neighborhoods.

One Jakarta resident after having lived on her rooftop for 7 days and 7 nights was glad that she was finally rescued. She also said that for the rest of her life she would not forget the experience. What baffled her though, was the severity of the flood. She was quoted in a weekly news magazine to say, "Five years ago, the water level was just two meters, now it is more than four meters," she said referring to the last major flood in 2002 that also partly submerged her dwelling. ${ }^{9}$ Another illustrative quote comes from Admiral Bernard K. Sondakh, the country's Navy Chief of Staff at the time, who lived at the Naval Officers residential complex in Kelapa Gading, a wealthy neighborhood. He was very taken aback by the severity of the flood. "I never imagined the floods would be so devastating," he said. ${ }^{10}$

The 2007 flood was not the only disastrous episode to have occurred in Indonesia in the past decade. Prior to this, a series of disasters and accidents such as the 2004 Indian Ocean tsunami that swept Aceh and the island of Nias, the Yogyakarta earthquake and the hot mud flow in Sidoarjo, East Java in May 2006, prompted a number of Indonesians to

\footnotetext{
${ }^{7}$ Hilgartner, “The Social Construction of Risk Objects," pp. 48-50.

8 Hilgartner, "The Social Construction of Risk Objects," p. 43.

9 “Di Balik Banjir Jakarta,” Tempo, 18 February 2007, p. 90.

10 “Naval Rescue," Tempo English Edition 19 February 2007, p. 57.
} 
speak out for the need of better disaster preparedness (one proposal is to mobilize the military) and the awareness of living in precarious environments. ${ }^{11}$ Their calls for changes in the culture of disaster preparation and mitigation illustrate that even "natural disasters" will, in the words of Stephen Hilgartner, "inevitably implicate human artifacts, organizations, and choices." 12

In addition, a number of public transportation accidents that occurred in 2006 and early 2007 eroded the public's trust in the government to prevent and handle sociotechnical disasters. ${ }^{13}$ They lost their trust in the government's capacity to protect them from harms. As Langdon Winner argues, in a democratic society, trust is an important element that the public needs to cope with the vulnerability of their socio-technical world. According to Winner, the public reasonably expect, "that key technologies will always work reliably and not break down in ways that jeopardize [their] health, safety and comfort." 14

In the light of these other disasters, the motivations for the various actors who participated in the debate about Jakarta's floods were high. Many people were united in their desire to reduce the incidence and severity of flooding in the future. They didn't want the same major flood to occur again in the city because it was a big ordeal for them. Some people's lives were also at stake. Many believe that Jakarta's development was headed in the wrong direction and parts of the city would be permanently under water in the future, unless something were to be done to prevent it immediately. They were also concerned about the diminishing carrying capacity of the city to support the continually increasing population. Put in another way, the public wanted assurances from the government that they could trust public officials to reduce the risk of flooding in Jakarta by doing something about it.

The issue of trust, I think, was also in the mind of a number of government officials. Some state actors wanted to be perceived to be more responsible in handling disaster (i.e. to be more accountable to the public). To Fauzi Bowo and Adang Daradjatun, who ran as candidates in the first-ever Jakarta's gubernatorial election in August 2007, the stake was the outcome of the election. They wanted Jakartans to think that they cared and had solutions to the flood problem. Prior to August 2007, Jakarta's governors were appointed by the Jakarta's Regional Representative Council (Dewan Perwakilan Rakyat Daerah, $D P R D$ ), usually with a nod from the president. Sutiyoso, who was appointed governor in 1997 and was the city's governor when the 2002 flood occurred, had a little political stake in the debate following that flood. He did not have to answer to Jakarta residents who did not elect him. In fact, the Jakarta's parliament elected him again for his second and last term in 2002.

Equally important to note is that the debate following the 2007 Jakarta flood was made possible, in large part, by a shift of the sociopolitical condition in the country. The socalled reformasi era began after the fall of Suharto, Indonesia's second and longest serving president, on May 21, 1998. The sudden and quite unexpected timing of his resignation came after days of student protests and riots in Jakarta. Initially, the students protested the increased prices of fuel and other essential goods after the government, following a

\footnotetext{
11 Roch Basoeki Mangoepoerojo, “Tentara di Negeri Bencana,” Kompas 19 June 2006; Lily Yulianto Farid, "Hidup di Negara Rawan Bencana,” Kompas 1 April 2005.

12 Stephen Hilgartner, "Overflow and Containment in the Aftermath of Disaster," Social Studies of Science 37/1, 153-158, p. 153.

${ }^{13}$ Adam Air Flight 574 disappeared near Polewali, Sulawesi on 1 January 2007, passenger ferry Levina 1 caught fire in Java Sea on 22 February 2007 and later sunk, and another Adam Air airplane that broke its fuselage upon landing on Juanda airport in Surabaya on 21 February 2007.

${ }_{14}$ Langdon Winner, "Trust and terror: The vulnerability of complex socio-technical systems" Science as Culture, 13 no. 2 (June 2004), pp. 155-172.
} 
prescription by the IMF, pulled out gasoline subsidies in order to receive funds from the international agency. The Indonesian government needed the bailout money to remedy the economic situation following the Asian financial crisis that started a few months earlier. When in early May a peaceful student demonstration resulted in six college students shot and several wounded, riots followed and engulfed the city. Suharto, who was in Egypt at that time, cut his overseas trip short to address the mounting political crisis. He promised to reshuffle his cabinet and to implement reform, but several ministers decided not to rejoin his new cabinet. In the mean time, more public figures called for Suharto's resignation and students made their way to the parliament building and occupied it for a few nights. Three days after a televised address in which Suharto announced that a new election would be held and he would not run again, he resigned and Vice President B.J. Habibie was sworn in as the new leader.

What followed was a tumultuous period that marked political struggles among the ruling elites and between the state and the emerging civil society. President Habibie only managed to stay in power for a little over a year. Following the October 1999 general election, Abdurrahman Wahid (widely known as Gus Dur) was elected the president by the parliament. Two years later, he was removed from office by the same parliament because of his controversial style of governance, and Vice President Megawati Sukarnoputri was appointed the new leader of the country. In an unprecedented direct presidential election in 2004, Megawati lost her re-election bid, and Susilo Bambang Yudhoyono (commonly known by his acronym SBY) won the popular vote and was sworn in as Indonesia's fourth president since Suharto's fall.

The revolving door of leadership at the top had several consequences for governance in Jakarta. The emerging civil society often took their concerns to the streets. The city between the late 1990s up until early 2000s, according to Merlyna Lim, became "a'demopolis' - literally a 'demos's polis' - a city ruled by people, or a democratic city; and a demo-polis, a city always teeming with demonstrations. Street demonstrations were held every day and became something of a routine." ${ }^{15}$ In an effort to suppress these protests, the Sutiyoso administration "renovated" the Hotel Indonesia Roundabout (Bunderan Hotel Indonesia), the most popular site of holding the demonstrations, to make it more difficult for people to congregate. Despite an effort to "discipline the public space," Jakartans learned that they could use civic spaces to voice their concerns. ${ }^{16}$

The current Indonesian democracy, thus, has the following characteristics: emerging civil societies as indicated above, free elections of many public officials from the presidency on down to mayor ship, multi-party political system and competitions among those parties to gain power, free press, and decentralization of power. But despite these gains, one scholar notes that money politics and corruptions are still rampant. ${ }^{17}$

The implications of the political shift are quite significant. Before the reformasi era, particularly during Suharto's New Order, the state dominated socio-technical decisionmakings. Many projects (typically large projects) were launched and built to achieve the political legitimacy of the New Order regime by claiming those projects as projects of national importance. Two examples are the state-owned aircraft industry ${ }^{18}$ and the

\footnotetext{
15 Merlyna Lim, "Transient Civic Spaces in Jakarta Demopolis" in Globalization, the City and Civil Society in Pacific Asia: The Social Production of Civic Spaces, ed. Mike Douglas, K.C. Ho and Giok Ling Ooi (London; New York: Routledge, 2008), p. 220.

16 Lim, “Transient Civic Spaces in Jakarta Demopolis,” p. 225.

17 Vedi R. Hadiz, “Indonesia a Decade After Reformasi: Continuity of Change?” ISEAS conference paper, 2008, p. 2.

18 Sulfikar Amir, "Nationalist rhetoric and technological development: The Indonesian aircraft industry in the New Order regime,” Technology in Society, vol. 29 (2007), pp. 283-293.
} 


\section{The 2007 Jakarta Flood and The Debate On Jakarta's Future Water Infrastructure}

launching of a communications satellite called Palapa. ${ }^{19}$ Nowadays, non-state actors are openly and actively engaged in public decision-making, including those related to technology. For the first time in many years, the public was made aware of the multitude of problems the 2007 flood exposed. The flood episode along with the shift in political setting opened the floodgate, so to speak, of discussions. Government's proposed solutions, technological interventions, and policies are constantly under scrutiny. Many actors used the 2007 flood to make all kinds of critiques, not just of the city's built environment, but also about Indonesian democratic practices in general.

\section{Mapping the Flood Debate}

One way to conceptualize the 2007 flood debate is to analyze it as a social construction of risk objects. One part of the debate, for example, revolves around the issue of land subsidence in the city. Many actors argued that this situation poses a dangerous consequence. They said that the city has been sinking and coupled with the rise of sea level, much of North Jakarta could be permanently submerged unless the city did something to prevent it now. ${ }^{20}$ One dire warning came from Hongjoo Hahm, the lead infrastructure specialist at the World Bank in Jakarta at the time. He claimed that the State Palace, which is located in the middle of the city, could one day have a "sea-front view." 11 The institution where Hahm worked had proposed a solution to mitigate future flooding. Recently the World Bank has agreed to finance a massive, multi-year dredging effort to return the original capacities of rivers and drainage canals in Jakarta. ${ }^{22}$ Jakarta Globe, the newspaper that ran a special issue on Jakarta's water woes on its July 24, 2009 edition supported this proposed technological intervention. Noting that Jakarta's water problems involve "the supply [of potable water], the [absence of] sewage [system], the floods, the garbage, [and] the tides" the newspaper pointed to those five entities as risk objects that need to be controlled. ${ }^{23}$ Almost exclusively, the paper cited the World Bank's assessment of the city's conditions and the bank-sponsored dredging project as a viable solution to manage all of those risks. But taking such a stand is not the monopoly of Jakarta Globe. Other newspapers are also inclined to highlight certain solutions to solve the flood problem. Republika, another daily that is widely read by Jakartan Muslims, published an interview with the inventor of biopore holes who invoked a verse from the Qur'an as an aspiration for inventing the technology, something that would surely appeal to many Republika readers. ${ }^{24}$ In the hope of gaining wider readership, Republika featured a number of articles about the biopore holes.

Other actors also mentioned the risk associated with a sinking city. One official with the country's Meteorology, Climatology, and Geophysics Agency (Badan Meteorologi Klimatologi dan Geofisika, BMKG) explicitly pointed out the dangerous effect of land subsidence and that the city needs to address this "non-meteorological factor"

\footnotetext{
19 Joshua Barker, "Engineers and Political Dreams: Indonesia in the Satellite Age," Current Anthropology, 46, no. 5, (December 2005), pp. 703-727.

20 Rieska Wulandari and Reynold Sumayku, "Pesisir Jakarta: Menata Timbunan Masalah Dengan Masalah," National Geographic Indonesia, July 2008.

21 Putri Prameshwari, “The Tides,” Jakarta Globe, 24 July 2009.

22 World Bank, "Jakarta Urgent Flood Mitigation Project". The documents can be accessed online at: http://www.worldbank.org/projects/P111034/jakarta-urgent-flood-mitigation-project?lang=en (accessed on 19 March 2015).

23 “Water Worries: What's Wrong With Jakarta's Water and What Can Be Done?” Jakarta Globe, 24 July 2009.

24 “Membangun Istana Cacing," Republika, 20 May 2007.
} 
immediately. ${ }^{25}$ In this example, an actor explicitly links an object and a presumed harm. But participants in the flood debate did not just point to one risk object; they often constructed a chain of risk objects (i.e. chain of causations) in the discourse. The city was sinking, they pointed out because in large part there was an inadequate potable water supply to Jakarta residents, which requires many buildings to draw water from the underground aquifers. And since there was no clear regulation about aquifer discharge, the rate of water pumping was shown to be larger than the rate of recharge. ${ }^{26}$ Other actors, such those who worked for the Jakarta Water Supply Regulatory Body, admitted that part of the reasons that there was not enough drinking water for the city's residents was because there was inadequate raw water that could be processed by the city's state-owned water operator Perusahaan Air Minum Jaya, or PAM Jaya. ${ }^{27}$ The main reason for this, they asserted, was polluted surface water, which in turn was caused by the trash and other pollutants that were being dumped into the rivers and canals by squatters and factories. Factories did it because they did not want to treat their waste and they were able to do this because laws regulating industrial waste disposal were hardly enforced. The reason that they were many urban poor living on the river embankments was due to rapid urbanization, which was caused by centralized development in Jakarta, and so on. Firdaus Ali, a University of Indonesia environmental engineer once told me, "it's a flood of people, not a flood of water [that we have here]."28

Rapid urbanization was invoked not only as a risk object, but also as the result of uneven development occurring in the country, a risky endeavor. Ivan A. Hadar, a director of the Indonesian Institute for Democracy Education (IDe), wrote an op-ed piece highlighting the unevenness of development by saying that two-third of the foreign investment and forty-five percent of domestic capital was put in Jakarta during the three decades of the New Order rule. As a result, he wrote, "It is no wonder the population has always been increasing, from 450,000 in 1930 to 9.8 million in 1995 and about 12 million today." ${ }^{29}$ Deden Rukmana, an urban studies and planning professor at Savannah State University was more direct in his criticism about this issue. In a 2008 blog post, he disputed the claim made by Basah Hernowo, the director of forestry and water resource conservation at the National Development Planning Board (Badan Perencanaan Pembangunan Nasional, Bappenas), that the flood was caused by poor drainage system, a risk object that some actors identified. Rukmana wrote,

\begin{abstract}
Neither improving the drainage system nor dredging the canal and rivers is a sustainable solution for the annual floods in Jakarta. The annual floods are strong evidence that rapid urbanization in Jakarta must be reduced. One way to reduce the rapid urbanization in Jakarta is to eliminate the pull factor of urbanization. One major pull factor of urbanization in Jakarta is its function as economic, commercial, cultural and transportation hub of the nation as well as the capital of the country. Indonesia needs to redistribute the central functions from Jakarta to other parts of the nation and create more urban agglomerations to pull urbanization away from Jakarta. Relocating central functions out of Jakarta will not only make Jakarta more sustainable but also create regional equality in Indonesia. ${ }^{30}$
\end{abstract}

\footnotetext{
25 “Banjir Pantai Terjadi Sampai April," Kompas 14 January 2008.

26 Titania Febrianti and Reynold Sumayku, “Air Bersih Jakarta,” National Geographic Indonesia, August 2009.

${ }^{27}$ Semi-structured interview with Firdaus Ali through email, 4 September 2009.

28 Interview with Firdaus Ali, Jakarta, 12 June 2009.

29 Ivan A. Hadar, “Banjir dan Daya Dukung Ekologis,” Kompas, 7 February 2007.

30 Deden Rukmana, “Jakarta Annual Flooding in February 2008,” February 5, 2008.

http://indonesiaurbanstudies.blogspot.com/search?q=banjir+jakarta (accessed 30 September 2009).
} 
A growing chorus of such criticism was aimed to dispel the notion that technological fix alone (one attempt to control risk objects) would solve the flood problem.

The chain of causation that the actors created in the debate, though theoretically can be indefinited, often stopped at an endpoint, particularly when they wanted to propose a solution. For example, along one the chains of causation I highlight above, several solutions had been proposed to control or displace a risk object associated with a sinking city. Several actors, for instance, argued for the need to dredge the rivers and canals to solve the surface water pollution problem. In fact, the Jakarta provincial government (Pemerintah Daerah Khusus Ibukota Jakarta, Pemda DKI Jakarta) planned to dredge all the rivers and drainage canals in the city and it tried to come up with a solution to relocate the people who were living on the river embankments and along reservoirs. ${ }^{31}$ One of my interviewees wondered why could not Jakarta pipe spring (and thus potable) waters that are abundant in the mountainous region located south of the city. Many cities in Europe, he told me, channel their potable water using underground pipes. This way, he said, aquifer pumping and subsequently land subsidence could be halted and the city's water supply problem can be solved. ${ }^{32}$ In suggesting this solution, he intended to displace a risk object (aquifer pumping) by not taking into considerations other processes such as the need to supply and treat raw water. The assumption embedded in his argument was that laying underground pipes from areas outside Jakarta's jurisdiction would pose no issues both technologically and politically. Perhaps there would be a little technological problem. But in the climate of decentralization during the reformasi era, provincial governors and many sub-district heads have been trying to exert their authority in governing their regions more than before. Piping water from sources outside the jurisdiction of Jakarta could potentially create a conflict that would not be easy to negotiate. One indication of this potential conflict lay in the difficulty that the Jakarta's government in pushing its proposal to enlarge the administrative area of the city to include its neighboring regions and towns. This proposal came from Sutiyoso, Jakarta's former governor, who reasoned that since Jakarta's rivers originate in the south and the 2007 flood inundated neighboring areas, Jakarta would not be able to solve the flood problem alone: it needed to have a larger administrative area, a concept he termed the "Jabodetabekjur megalopolis." 33 Sutiyoso also believed that this proposal would be able to solve other issues that the city faces including garbage, urbanization, transportation, pollution, housing, poverty, and water supply. But the then governor of the neighboring new province, Banten, created using the country's decentralization law, resisted this effort. In the midst of the debate of this proposal, she was quoted as saying,

As a governor I welcome the idea of the formation of the megapolitan concept if the only goal is to integrate spaces in the three provinces. But we ask that this concept does not impinge on the autonomy of Banten as a province because [Bantenese] has fought a long [battle] to create the province of Banten." ${ }^{34}$

Another solution to solve the water supply problem, quite prominent among the many solutions proposed, is to build a long, underground water and road tunnel from central to North Jakarta along the Ciliwung River, one of the more than a dozen rivers that pass

\footnotetext{
31 Dewi Kurniawati, “Dredging the Rivers Means Uprooting Thousands of Squatters,” Jakarta Globe, 24 July 2009. One successful attempt to relocate squatters along a reservoir in Jakarta called Waduk Pluit was successfully carried out by then Governor of Jakarta Joko Widodo and his Deputy Governor Basuki Cahya Purnama in 2013.

32 Interview with one of my informants, Jakarta, 17 June 2009.

33 Jabodetabekjur is a portmanteau word of Jakarta and its neighboring cities and regions: Bogor, Depok, Tangerang, Bekasi, and Cianjur.

${ }^{34}$ Anita Yossihara, “Cukup Memadukan Tata Ruang,” Kompas, 17 February 2007.
} 
through the city. Dubbed the Multi Purpose Deep Tunnel (MPDT), its proponents claimed that not only would it solve Jakarta's water supply issues (by collecting, channeling, and storing runoff water in an underground water cistern), but also (and more importantly) reduce the risk of flooding, collect and treat sewage, facilitate river restoration, recharge aquifers, prevent seawater intrusion, and alleviate traffic congestion. This particular solution attempts to control multiple risk objects simultaneously. In fact, the multi functionality of the proposal gained the attention of Governor Sutiyoso who readily adopted the idea and sold it aggressively to Jakartans. ${ }^{35}$ Another aspect of the proposal that appealed him was the promise of sidestepping the problem of land appropriation and compensation, ${ }^{36}$ an issue that continues to plague the construction of the East Canal Flood (Banjir Kanal Timur, BKT), a technological project that was under construction in 2007 to mitigate flooding. ${ }^{37}$

Other people, however, perceived the canal as more an emplacement of a risk object rather than an attempt to displace another. Many believed that the canal itself would contribute to the increased risk of flooding because the idea behind it is to channel water out to the sea quickly instead of allowing the water to percolate underground to recharge the aquifers. Mulyono Karim, a Kompas reporter, criticized the East Canal Flood project, asserting that the real problem lies in Jakarta's conventional drainage system, which was based on an outdated principle of collecting and delivering rainwater quickly to the Jakarta Bay. What Jakarta needs is a new concept he dubbed "eco drainage," whereby rainwater should be allowed to seep into the ground as much as possible. Instead of building the East Canal Flood, Jakarta would be better served by building more parks, inner city woods, and seepage wells, he opined. ${ }^{38}$ Using a similar reasoning, there was another proposed solution that was gaining the public's attention, called the biopore holes (Lubang Resapan Biopori, $L R B$ ). The concept behind this technical intervention was to displace a risk object (impermeable topsoil and concrete surface) that contributed to land subsidence, by transforming the soil condition to allow rainwater to recharge underground water.

Land subsidence and inadequate water supply were not the only risk objects that actors in the debate constructed. Several actors pointed to the practices of deviating from the city's first master plan as the primary cause of flooding. One of them is Garundono, Deputy Head of the Committee for the Evaluation of Urban Environment, who contended that the Jakarta administration didn't build the Capital according to the city's original master plan. ${ }^{39}$ The first post-independence comprehensive city planning, called the Master Plan 1965-1985 (Rentjana Induk Djakarta 1965-1985), was drawn up in the 1960s by the then Governor Sumarno's administration and later adopted by his successor, Ali Sadikin. This master plan specified that the eastern region of Jakarta (including what is now the regularly flooded Kelapa Gading neighborhood) to be part of a horseshoe-shaped open spaces (greenbelt) encircling the city (Figure 1).

\footnotetext{
35 “Proyek Mega Mencegah Banjir," Gatra, 31 May 2007.

${ }^{36}$ Semi-structured interview with Firdaus Ali through email, 4 September 2009.

37 “The Eastern Flood Canal Feeding Frenzy,” Tempo English Edition, 9 April 2007.

38 Mulyawan Karim, "Drainase Jkt, Tak Terpelihara dan Ketinggalan Zaman,” Kompas 3 February 2007.

39 "Bursting at the Seams," Tempo English Edition, 19 February 2007.
} 


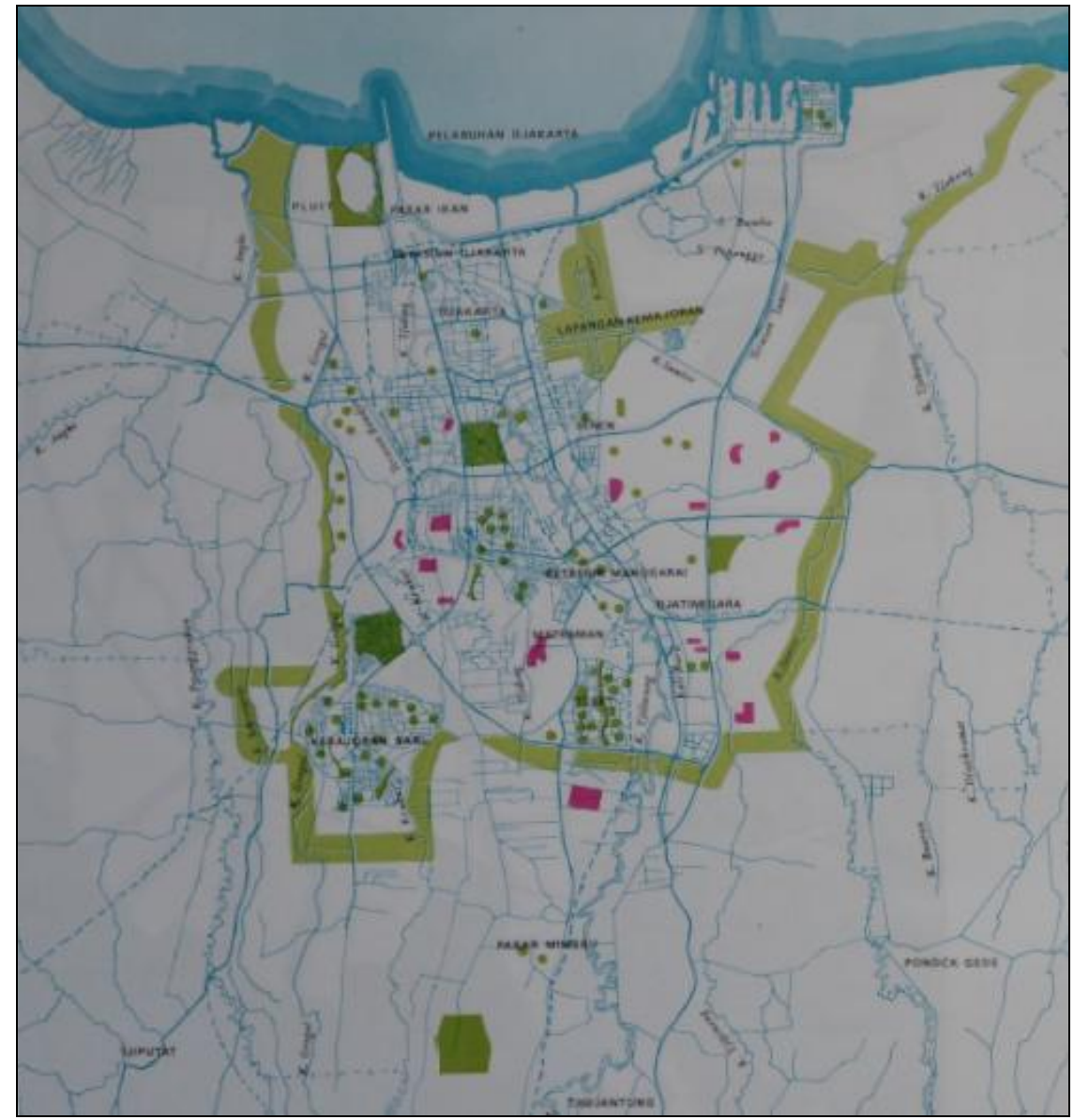

Sumber: Rentjana Induk Djakarta 1965-1985

Figure 1. Open Spaces

The idea was to have these green areas reserved for parks that Jakartans could enjoy and to absorb rainwater. But these planned parks, inner city woods, and water catchment areas were later erased in the subsequent 1985-2005 Master Plan. In their place, a concrete jungle was erected instead. Malls and luxury apartment complexes mushroomed in the last decade. There are about one hundred malls in Jakarta today, in the capital city of a country with an average income of USD1300 per year. ${ }^{40}$ As a result, the city's 2010 Master Plan devotes an even smaller portion of the city to open spaces since many of these areas have been converted to built-environment. ${ }^{41}$ When actors spoke out about this issue, they tended to point to broader underlying problems; predatory business interest and corrupt government officials. Eko Budiharjo, a professor of architecture and former rector of the University of Diponegoro, summed up the effects of these practices on Jakarta by saying, "spatial planning in Indonesia is no different from money planning... whoever has the strong finances will determine the face and the fate of the city." 42 Big Business, typically represented by powerful real estate developers, and the corrosive practices of corruption were emplaced as risk objects in the network.

\footnotetext{
${ }^{40}$ Heri Susanto, “Jakarta, Mall City,” Tempo English Edition, 6 November 2006.

41 “Ongkos Ekonomi Yang Mesti Dibayar,” Kompas, 11 February 2007.

${ }^{42}$ Eko Budiharjo, “Kota-kota yang Terluka,” Kompas, 6 February 2007.
} 
Some actors, however, tried to resist the emplacement of risk objects mentioned above by trying to sever the link that those objects have with any supposed dangers. Instead they emplaced a new risk object by faulting the environment. They claimed that the 2007 flood was part of the "cyclical nature" of big floods that come in five-year cycles. The "five-year cycle" floods dominated the rhetoric especially among members of the political elite; Governor Sutiyoso is a well-known one among them. They kept invoking this as if it were a fact, largely to dismiss alternative explanations of the cause of flooding. This claim has, of course, been disputed (i.e. displaced) by a number of people. One of them is a climatologist with the Bandung Institute of Technology. Dr. Armi Susandi contended that the past three big floods spanning twelve years did not provide enough data to assert the five-year cycle theory. In an article published in the daily Kompas, he was quoted to say that only a layperson would say that Jakarta's big flood comes in five-year cycles. ${ }^{43}$ The way Susandi framed his argument, I think, served two purposes. Not only did he want to definitively discount the nature-causes-the-flood theory, but he also wanted to exert his authority as a noted scientist. This way, he lent credibility to Kompas's assertion that the five-year-cycle flood is a myth.

The examples above illustrate that actors identified a variety of objects, which can be things, events, conditions, or even behaviors and linked them as the sources of or the entities that pose risk to flooding in the city. The examples also show how different actors understood the flood differently. Often (though not always), their organizational affiliation, educational background, professional experiences, and sociopolitical standing shaped those varied understandings. In their rhetoric actors emphasized some risk objects more so than the others. One important consequence was that although the networks of risks constructed were complex, only certain risk objects and technological proposals to control them gained the public's attention. For example, there was an academic who recounted the successful story of the city of Curitiba in Brazil that managed to solve its urban problems similar to the ones that Jakarta was facing. Drawing the lessons from that particular case study Eko Budiharjo, a professor of architecture and a member of the National Commission on Habitat, proposed what he termed the "Ten Commandments of Sustainable Urban Development," which were ecological balance (environment), providing jobs (employment), enabling society (empowerment), obeying the law (enforcement), involving private entities (engagement), ensuring the comfort of city residents (enjoyment), employing the ethics of development, upholding justice (equity), practicing energy conservation, and paying attention to environmental aesthetics. ${ }^{44}$ Although quite persuasive, this proposal, like many other proposals put forth by other individuals did not garner much attention. It was drowned, so to speak, by other proposals.

The fact that many actors came up with many solutions to mitigate Jakarta's floods did not necessarily mean that their solutions would be readily adopted by the city government or by the public, either. Proponents of each of these proposals competed to gain wide public support as well as political backing. When certain proposals fell out of favor or did not get enough attention, they would employ any number of combinations of the following tactics to convince either the public or decision makers to use their technologies: writing op-ed articles, holding press conferences, conducting interviews with the media, holding seminars, or preparing presentations and videos about their technologies. They did so, I argue because they wanted to achieve a desired political goal with their technical interventions and proposals. In this case, the technology and political maneuvering went hand in hand. In the next two sections, I will highlight two of the well-

\footnotetext{
43 Brigitta Isworo Laksmi, "Banjir Lima Tahunan Hanya Sebuah Mitos,” Kompas, 14 February 2007.

44 Budiharjo, "Kota-kota yang Terluka".
} 
known proposals to illustrate the intertwining relationship between technology and politics: the MPDT and the biopore holes.

\section{Multi Purpose Deep Tunnel (MPDT)}

Out of the many state-sponsored technological proposals to solve Jakarta's flood problem, perhaps the Multi Purpose Deep Tunnel (MPDT) was illustrative of the kind of centralized effort favored by the state. But unlike many other state-backed projects, this particular solution promised not only to solve Jakarta's flooding and other related problems, but also claimed to be a revenue-generating enterprise, the kind that Jakarta government preferred. The income factor was a very important aspect, one of the project proponents told me because it would ensure the continual operation and maintenance of the system in the long run. ${ }^{45}$ Many public infrastructure projects in the city suffer from lack of maintenance, many people said since not enough funding was available. The earnings from MPDT would be generated from collecting the toll fees from the tunnel's multi-lane highway users, selling the collected rain water to PAM Jaya, and selling the processed solid waste from its sewage treatment facility as bio fertilizer. Despite the seemingly profitable aspect of the project, there was no consensus among the actors in the flood debate that this is an important factor to consider in creating an infrastructure to control flooding in the city. It seemed that proponents the tunnel added this feature to help sell the idea to the Jakarta administration.

The tunnel was also touted as a green technology because the tunnel highway ventilation system wanted to incorporate a carbon capture mechanism and to run on methane gas generated from anaerobic process of the liquid waste collected by the tunnel. ${ }^{46}$ In other words, the technology promised to produce all kinds of material effectiveness. In the case of MPDT, the Jakarta government under Governor Sutiyoso liked the proposal, adopted it immediately, and advocated it vigorously. ${ }^{47}$ Since the technology was claimed to be modeled after the Chicago's Deep Tunnel Reservoir System (DTRS) and the Kuala Lumpur's Storm Water and Road Tunnel (SMART), Sutiyoso and his entourage paid a visit to Kuala Lumpur, Malaysia in late July 2007 to study how SMART works. ${ }^{48}$ Firdaus Ali, the vocal champion of this proposal admitted that he first conceived the technology to solve the problem of raw water supply (and it is still the main objective), but he said that it would solve the flood problem, too. Entrenched in the proposal, I think are hidden political agendas. Sutiyoso wanted to use this proposal to bolster his proposed Jabodetabekjur megalopolis concept since the two were in tandem with each other. The Jabodetabekjur would provide the administrative while the tunnel would provide the technological means to solve Jakarta's multitude problems. Critics say that Sutiyoso wanted to create a new position for himself after serving his second term as Jakarta governor. Kompas newspaper ran a special Focus (Fokus) section debating the merit of this megapolitan concept that included a poll of people who were living in the Jabodetabekjur area. It is interesting to note that about fifty-four percent of the respondents said that they welcomed the idea. A majority seemed excited with the prospect of being labeled as Jakarta resident. They were also optimistic that the enlarged administrative region would help improve city planning, provide better housing and transportation, and would be generally conducive for businesses. But for the most important issue to which this concept

\footnotetext{
${ }^{45}$ Semi-structured interview with Firdaus Ali through email, 4 September 2009.

${ }^{46}$ Semi-structured interview with Firdaus Ali through email, 4 September 2009.

47 "Proyek Mega Mencegah Banjir".

48 DKI Pelajari Pola Pengaturan Deep Tunnel Kuala Lumpur, Suara Pembaruan, 23 July 2007.
} 
was proposed, they said that they were not confident that it would solve the flood problem. ${ }^{49}$

In addition to serving Sutiyoso's own political ambition, the tunnel project would seem to likely serve some of its strongest advocates politically. Most of the MPDT proponents worked with the Jakarta Water Supply Regulatory Body (JWSRB). In proposing this particular technical intervention, they seemed to want to increase and strengthen the role of this body in matters of a vital public service. When Suharto resigned, the Jakarta administration was forced to renegotiate the contracts it had with two private partners of PAM Jaya to distribute drinking water to Jakarta residents. Part of the stipulation of the Restated Cooperation Agreement, or RCA, signed in 2001, was the founding of the JWSRB whose role, according to $\mathrm{H}$. Angga Indraswara, "was to mediate the interests of all related parties in the implementation of the RCA. In addition, [the RCA allows] each of the five municipalities in Jakarta established a Komite Pelanggan Air Minum (Water Users' Committee), which would act as an advocacy group for the public." ${ }^{50}$ Indraswara points out that despite this RCA, many Jakartans, particularly the poor, still do not receive adequate clean waters for daily use because the private distributors treat water as other profitmaking commodities. He proposed to transform the role of the Water User's Committee "from water users into water 'watchdogs' who ensure that the private water operators meet their responsibility to pursue the universal provision of clean water to all segments of the society." ${ }^{1}$ Such proposal would, of course, undermine the role of the regulatory body. One way to strengthen the role of the JWSRB was by showing to the public that it was serious in serving and protecting their interest. By claiming that the tunnel project would provide raw water to be processed and deliver to the public, the JWSRB as an institution would gain standing with the Jakarta administration as well. This would ensure the longevity of the Regulatory Body as a functioning organization. To propose a solution that promises to solve several of Jakarta's water woes simultaneously was even better since it would enhance the Regulatory Body's reputation in the eyes of both the public and the state.

As of December 2009, the status of the tunnel project was uncertain. Sutiyoso, the most prominent supporter of this project, after stepping down as governor of Jakarta expressed a bigger political ambition. He announced his intention to run in the country's July 2009 presidential election. ${ }^{52}$ His plan did not materialize, but his blatant display of political drive had a consequence that was deemed unfortunate by the MPDT backers. Then Vice President Jusuf Kalla asked him to set aside the pre-feasibility study of the PDT.53 In this case, technological development was tightly linked with political development.

\section{Biopore Holes}

While the tunnel proposal uses a more centralized approach with a small number of people involved, the advocates of the biopore holes (Lubang Resapan Biopori, LRB) emphasized a more democratic approach by highly encouraging any willing citizens to adopt the technology. Many people, in fact, were persuaded by the effectiveness of this technology and have created the biopore holes on their own. The inventor of the

\footnotetext{
49 BE Satrio, "Megapolitan Tak Cukup Meyakinkan,” Kompas, 17 February 2007.

${ }^{50}$ H. Angga Indraswara, "Water Woes" Inside Indonesia, January-March 2009 edition, accessible online at http://insideindonesia.org/content/view/1184/47/ (accessed 29 July 2009).

51 Indraswara, "Water Woes".

52 "Sutiyoso Siap Jadi Capres," Kompas Cyber Media, 29 September 2007.

53 Semi-structured interview with Firdaus Ali through email, 4 September 2009.
} 
technology, Kamir R. Brata, a soil scientist at the Bogor Institute of Agriculture (Institut Pertanian Bogor, IPB), claimed that biopore holes help modify the soil ecosystem to allow more water to permeate underground and reduce the volume of household organic trash.

The idea behind the technology was to create a $1-\mathrm{m}$ deep, $10-\mathrm{cm}$ diameter hole and to put some organic materials in the hole to attract and feed worms and other microorganisms that would create many tiny pores inside the hole. This would transform impervious topsoil into a permeable layer allowing rainwater to trickle underground. The inventor claimed that the role of human would be "simplified" and the effectiveness of the technology, in essence, would hinge upon successfully enrolling microorganisms in the soil. 54

Brata aggressively promoted the technology. One strategy he employed was to entice people to come to his laboratory. He declared that the drilling tool he came up with would not be patented and everyone would be welcome to copy and use it. He was quoted to say, "You're welcome to come to IPB's Soil Laboratory in Dramaga to see or duplicate the drilling tool. What matters to me is that people can learn about these biopore holes and deem them useful." 55 Implicit in his statement is a strong desire to have this particular solution to reduce flooding to be one that could be widely adopted in Jakarta or in any other flood-prone regions.

Two months after the big flood engulfed Jakarta, Brata, his colleagues, 3000 IPB students, and Bogor politicians and residents drilled 5250 holes on April 22, 2007 (Earth Day) to signify the $525^{\text {th }}$ anniversary of city of Bogor that year. Their effort captured the attention of the media. ${ }^{56}$ Subsequently, the public grew aware of this technology and residents in other cities decided to try to use it too. Rachmat Witoelar, the country's then Minister of the Environment, and Jusuf Kalla, the vice president at the time, supported the technology. ${ }^{57}$ Their backings, however, were largely symbolic. The central government never issued a policy to push for this solution. Nor did the two politicians above have any direct role in spreading this technology to the masses. The city of Bogor acted on its own initiative. I think the mayor and local politicians wanted to promote not just the biopore technology, but also IPB, which is located there.

On the occasion of the celebration of Environmental Day in June 2007, the city of Bogor awarded IPB's Rector Dr. Ahmad Ansori Mattjik and Kamir Brata for their efforts in raising the awareness about the environment and for inventing the biopore technology respectively. ${ }^{58}$ Their achievements helped foreground IPB as an academic institution to be reckoned with. In one university ranking, IPB was placed fourth behind the University of Indonesia, Gadjah Mada University, and Bandung Institute of Technology. ${ }^{59}$ The institute's reputation as one of the top universities in the country is well-known, but its brand as an agricultural institute has eroded over the past years since more than half of its graduates have not gone on to work in the agriculture sector. ${ }^{60}$ Brata's invention and reputation as a prominent soil scientist help IPB regain its reputation as the country's top place to study agriculture.

In addition, since Brata claimed that his invention was an environmentally friendly

\footnotetext{
54 My email communication with the inventor, 9 November 2009.

55 “Warga kota Bogor Mulai Membuat Lubang Biopori," Kompas, 22 April 2007.

56 “Warga kota Bogor Mulai Membuat Lubang Biopori,” Kompas, 22 April 2007.

57 Catatan Ringan Nur Hidayat, "Lubang Resapan Biopori Sebagai Alternatif Penanganan Limbah Organik (Sampah),” http://bioindustri.blogspot.com/2008/10/lubang-resapan-biopori-sebagai.html (accessed 15 March 2015).

58 "Penemu Lubang Biopori Dapat Penghargaan," Tempo Interaktif, 11 June 2007.

59 “Agar Para Periset Tidak Kesepian,” Tempo, 31 May 2009.

60 “Perampingan 'Institut Pleksibel Banget”” Tempo, 4 May 2008.
} 
technology, which many people seem to agree, the biopore hole helped underscore IPB's commitment to protecting the environment. In the media, Brata promoted his particular brand of environmental philosophy. He was quoted as saying, "An ecosystem is a system formed with interdependency between its components. All components must be considered in any conservation effort." 61 In other words, he disliked the idea that solving water and waste problem requires shifting or moving the materials elsewhere in the environment resulting in the destruction of that area (e.g. open garbage disposal sites, effluent-laden rivers, etc.)

Many advocates of this technology, who were consisted of not just the inventor, his colleagues, and IPB students, but also many regular citizens and politicians alike, liked to point out the ease of using this technology. One young blogger who lives in the nearby city of Bandung and works for a pharmaceutical company writes,

I am one of those who disagree with the [East] Canal Flood project in Jakarta (and a similar project in Bandung if there is one). To me, the essence of the project is to channel water out to sea as soon as possible. Rainwater is God's blessing that we need to store underground. ... Recently I found an interesting information about an alternative method to let water percolate underground. I found it in an interview transcript by Republika reporter with Kamir Raziudin Brata, an IPB researcher who has introduced a technology called biopore. ...The technology is really simple, [you] just need to create $1-\mathrm{m}$ deep and $10 \mathrm{~cm}$ diameter hole underground....You can create the holes even in your small backyard. ...I created about 10 biopore holes with family members in our backyard. ${ }^{62}$

Blogs promoting the technology such as the one above numbered in dozens and were multiplying quite rapidly. They either contained the blogger's description, step-by-step instruction, assessment, or experience of making the holes. Several newspapers have also written about the technology and interviewed its inventor. Kompas, for example, has written considerably about the biopore holes, chronicling the growing popularity of the technology since it was introduced in Bogor in April 2007. In December 2007, on the onset of a flood season in Jakarta, a reporter for the newspaper strongly encouraged Jakartans to apply the technology. She wrote, "Considering how easy and cheap it is to create biopore holes, there should not be any more excuses for Jakartans not to create them on their backyard. It's time for Jakarta residents participate to save Jakarta from floods."63

A few Jakarta administration officials finally took notice. Mayor of Central Jakarta Sylviana Murni for example, said that there have been about 3000 biopore holes created in her region. But demands from Central Jakartans to construct biopore holes kept growing. ${ }^{64}$ Brata and his team have calculated that the city would need 76 million holes to effectively prevent future flooding. Their proposal has, of course, met some criticisms. Firdaus Ali, who opposed this solution, contended that it would be better to halt aquifer discharge than to build 76 million biopore holes in Jakarta. ${ }^{65}$ Despite such comment, more and more Jakartans have taken up the technology. As recently as in September 2009, the Indonesian

\footnotetext{
61 Matheos Viktor Messakh, “Kamir Raziuddin Brata: Finding a Holistic Solution,” The Jakarta Post, 17 February 2009.

62 Cerita Pendek Warna-Warni Dunia Shinichi, "Biopori Against Kanal Banjir dan Kekeringan,” http://duniashinichi.blogspot.com/2007/06/biopori-against-banjir-kanal-dan.html (accessed 15 March 2015).

63 M. Clara Wresti, “Selamatkan Jakarta dengan Biopori,” Kompas, 26 December 2007.

64 "Peminat Biopori Tinggi, Harga Alat Pelubang Naik,” Kompas, 12 May 2008.

${ }^{65}$ Lubang Resapan Air Kurang Efektif," Republika, 4 April 2009.
} 


\section{The 2007 Jakarta Flood and The Debate On Jakarta's Future Water Infrastructure}

Red Cross created 5000 biopore holes in Jakarta and neighboring cities of Tangerang, and Bekasi to anticipate the upcoming flood season. 66

The wide adoption and eventually the planned massive scale implementation of this technology by the Jakarta's administration illustrate the successful strategies the Biopore supporters employed. Despite promises from some of the Jakarta administration officials to push for this solution in Jakarta, however, the city still fell short of the stated goal. Currently, there are 335,590 biopore holes in Jakarta, according to an official with the Jakarta administration, Muhayat.67 Jakarta Governor Fauzi Bowo issued an instruction No. $197 / 2008$ to speed up the creation of these biopore holes in the city, by requiring all the 20 agencies of the Jakarta administration to create biopore holes in their areas. ${ }^{68}$ Brata has calculated that as much as thirty percent of the city's organic trash would be reduced by the 76 million holes and water runoff will be drastically minimized. ${ }^{69}$ The governor's decree maybe indicative of two things: first, that his Jakarta administration had faith in this technology to solve the flood problem, and second, it wanted the public to see that it was supporting the spread of popular technology, and hence the public's approval. The latter was more likely than the former as it was constructing its own solutions to the flood problem, such as the East Canal Flood project and the river dredging effort.

\section{Conclusion}

A new sociopolitical condition in Indonesia has facilitated a vibrant discourse in the wake of socio-technical disaster. In a democratizing society such as Indonesia, state actors no longer monopolize the social production of risk objects. The public, who participate in the debate, help shape the networks of risks. Non-state actors manage to insert themselves into a sphere once dominated by the technocrats, in large part because the press was no longer controlled by the state. In doing so they exposed the messiness and vulnerability of a socio-technical system. The risky objects they identified run the whole gamut of entities that make up the entire system, which included water technologies, laws, practices, institutions, conditions, policies, and the environment. Not only did the actors identify multiple risk objects, but they also offered a variety of solutions to control or to displace them.

The presence and participation of the public in the debate also help deconstruct the typical causal chains put forth by the state by producing new causal ones. For instance, a few actors challenged the notion that one of the major causes of flooding was the urban poor's settlement on the river embankments. They did so by constructing a chain of risk objects that ended up pointing to a state policy that allowed such condition to occur in the first place, namely centralized development. The social construction of flooding risk in the city involves a constant battle of emplacing and displacing risky entities. Each act of emplacing and displacing a risk object was done with a particular motive to advance a certain objective. Embedded in many of the proposed solutions and the technical interventions was a certain goal that the actors want to accomplish. The agencies or institutions where these actors worked competed to grab both the public's and the state's attention and support. The stake in this competition was large. While many of them indicate that they wanted to prevent future flooding in the city, money, prestige, and power were also involved. Those whose ideas would be implemented or widely adopted stood to

\footnotetext{
66 “Antisipasi Banjir, 5000 Biopori Dibuat,” Kompas.com 13 September 2009.

67 “Jakarta Butuh 76 Juta Lubang Biopori,” Republika, 2 April 2009.

${ }^{68}$ Lubang Resapan Air Kurang Efektif," Republika, 4 April 2009.

${ }^{69}$ Lubang Resapan Air Kurang Efektif,” Republika, 4 April 2009.
} 
gain a lot of income and recognition that would elevate their own and their institutions' reputations. These exercises in linking technology with politics were exemplified by the two flood solutions that I have discussed above.

The debate also allowed many actors to contest the idea of modernity. Non-state actors continually challenged the state's understanding of what it meant to have a modern metropolis. They no longer bought the notion that to be modern Jakarta needed luxurious apartment complexes, malls, monuments, and skyscrapers. Many people made visible some of the problems that modernity brings: poverty, unemployment, inequity, illnesses, and technological risk. All the features of what the state thought made Jakarta modern were useless, many actors contended, if the city did not have functioning and adequate drainage, sewage, and transportation systems, protection from tidal flooding, green areas to absorb rainwater, affordable housing and job opportunities for the urban migrants, and other features they deemed to be equally important. Many people also pointed out that the 2007 flood affected both the rich and the poor alike, and since the flood did not discriminate, city planning was supposed to account for all residents of the city.

The debate about what Jakarta should do to reduce the risk of flooding in the city continued. As I have shown, although the Jakarta administration had come up with its own proposals and technical intervention, many Jakartans had taken up the biopore hole solution to show that they too have a stake in the future of Jakarta and needed to do something about it.

\section{Acknowledgement}

The author would like to thank Fadjar Hari Mardiansjah for his introduction to this journal. This paper was written as a second-year project of the author's graduate training in Science and Technology Studies Department at Cornell University and thus the author would like to thank his advisor Sara B. Pritchard for her guidance in completing the project.

\section{Bibiliography}

Agar Para Periset Tidak Kesepian. (2009, May 31). [Clipping from Tempo.] Copy in possession of author.

Amir, S. (2007). Nationalist rhetoric and technological development: The Indonesian aircraft industry in the new order regime. Technology in Society, 29, 283-293. doi:10.1016/j.techsoc.2007.04.010.

Amir, S. (2009). Challenging nuclear: Antinuclear movements in post authoritarian Indonesia. East Asian Science, Technology and Society: An International Journal, 3(2), 343-366. doi:10.1007/s12280-0099091-8.

Antisipasi Banjir, 5000 Biopori Dibuat. (2009, September 13). [Clipping from Kompas.] Copy in possession of author.

Banjir Pantai Terjadi Sampai April. (2008, January 14). [Clipping from Kompas.] Copy in possession of author.

Barker, J. (2005). Engineers and political dreams: Indonesia in the satellite age. Current Anthropology, 46(5), 703-727. doi:10.1086/432652.

Bijker, W. E. (2007). Dikes and dams, thick with politics. Isis, 98(1), 109-123. doi:10.1086/512835.

Budiharjo, E. (2007, February 6). Kota-kota yang terluka. Kompas.

Bursting at the Seams. (2007, February 19). [Clipping from Tempo English Edition.] Copy in possession of author.

Di Balik Banjir Jakarta. (2007, February 18). [Clipping from Tempo.] Copy in possession of author.

DKI Pelajari Pola Pengaturan Deep Tunnel Kuala Lumpur. (2007, July 23). [Clipping from Suara Pembaruan.] Copy in possession of author. 


\section{The 2007 Jakarta Flood and The Debate On Jakarta's Future Water Infrastructure}

Febrianti, T., \& Sumayku, R. (2009, August). Air bersih Jakarta. National Geographic Indonesia.

Hadar, I. A. (2007, February). Banjir dan daya dukung ekologis. Kompas.

Hadiz, V. R. Indonesia a decade after reformasi: Continuity of change? Retrieved from http://web.iaincirebon.ac.id/ebook/moon/Indonesia/s4_vedi.pdf.

Hilgartner, S. (1992). The social construction of risk objects: Or, how to pry open networks of risk. In James F. Short and Lee Clarke (Eds.), Organizations, Uncertainties, and Risk. Boulder, CO, San Francisco, CA, and Oxford, UK: Westview Press.

Hilgartner, S. (2007). Overflow and containment in the aftermath of disaster. Social Studies of Science, 371), 153-158. doi:10.1177/0306312706069439.

Hughes, T. P. (1983). Networks of power: Electrification in western society, 1880-1930. Baltimore: Johns Hopkins University Press.

Indraswara, H. A. (2009). Water woes. Inside Indonesia 95. Retrieved from http://www.insideindonesia.org/water-woes.

Jakarta Butuh 76 Juta Lubang Biopori. (2009, April 2). [Clipping from Republika.] Copy in possession of author.

Karim, M. (2007, February 3). Drainase Jakarta, tak terpelihara dan ketinggalan zaman. Kompas.

Kurniawati, D. (2009). Dredging the rivers means uprooting thousands of squatters. Jakarta Globe. Retrieved from http://jakartaglobe.beritasatu.com/archive/dredging-the-rivers-means-uprooting-thousands-ofsquatters $/$.

Laksmi, B. I. (2007, February 14). Banjir lima tahunan hanya sebuah mitos. Kompas.

Lim, M. (2008). Transient civic spaces in Jakarta demopolis. In Mike Douglas, K. C. Ho and Giok Ling Ooi (Eds.), Globalization, the City and Civil Society in Pacific Asia: The Social Production of Civic Spaces. London: New York: Routledge.

Lubang Resapan Air Kurang Efektif. (2009, April 4). [Clipping from Republika.] Copy in possession of author.

Mangoepoerojo, R. B. (2006, June 19). Tentara di negeri bencana. Kompas.

Membangun Istana Cacing. (2007, May 20). [Clipping from Republika.] Copy in possession of author.

Messakh, M. V. (2009, February 17). Kamir raziuddin brata: Finding a holistic solution. The Jakarta Post.

Naval Rescue. (2007, February 19). [Clipping from Tempo English Edition.] Copy in possession of author.

Ongkos Ekonomi Yang Mesti Dibayar. (2007). [Clipping from Kompas.] Copy in possession of author.

Pemerintah Daerah Chusus Ibukota Djakarta. (1967). Rentjana Induk Djakarta 1965-1985. Djakarta.

Peminat Biopori Tinggi, Harga Alat Pelubang Naik. (2008, May 12). [Clipping from Kompas.] Copy in possession of author.

Penemu Lubang Biopori Dapat Penghargaan. (2007, June 11). [Clipping from Tempo Interaktif.] Copy in possession of author.

Perampingan 'Institut Pleksibel Banget'. (2008, May 4). [Clipping from Tempo.] Copy in possession of author.

Prameshwari, P. (2009, July 24). The tides. Jakarta Globe.

Pritchard, S. B. (2011). Confluence the nature of technology and the remaking of the Rhone. Cambridge, MA: Harvard University Press.

Proyek Mega Mencegah Banjir. (2007). [Clipping from Gatra.] Copy in possession of author.

Satrio, B. E. (2007, February 17). Megapolitan tak cukup meyakinkan. Kompas.

Schiller, J., Lucas, A., \& Sulistiyanto, P. (2008). Learning from the East Java Mudflow: Disaster Politics in Indonesia. Indonesia, 85, 51-77. Retrieved from http://www.jstor.org/stable/40376444.

Susanto, H. (2006, November 6). Jakarta, mall city. Tempo English Edition.

Sutiyoso Siap Jadi Capres. (2007, September 29). [Clipping from Kompas.] Copy in possession of author.

The Eastern Flood Canal Feeding Frenzy. (2007, April 9). [Clipping from Tempo English Edition.] Copy in possession of author. 
Warga Kota Bogor Mulai Membuat Lubang Biopori. (2007, April 22). [Clipping from Kompas.] Copy in possession of author.

Water Worries: What's Wrong with Jakarta's Water and what can be done? (2009, July 24). [Clipping from Jakarta Globe.] Copy in possession of author.

Winner, L. (2004). Trust and terror: The vulnerability of complex socio-technical systems. Science as Culture, 13(2), 155-172. doi:10.1080/0950543042000226594.

Wresti, M. C. (2007, December 26). Selamatkan Jakarta dengan biopori. Kompas.

Wulandari, R., \& Sumayku, R. (2008, July). Pesisir Jakarta: Menata timbunan masalah dengan masalah." National Geographic Indonesia.

Yossihara, A. (2007, February 17). Cukup memadukan tata ruang. Kompas. 
58 The 2007 Jakarta Flood and The Debate On Jakarta's Future Water Infrastructure

JURNAL WILAYAH DAN LINGKUNGAN, 3 (1), 39-58 